\title{
Abstract
}

\section{Crimean-Congo Hemorrhagic Fever Outbreak in the North Region of Oman in August 2019: Case Series Study}

Khalid Saif Alsaadi ${ }^{1 *}$, BSc, MD, DEP; Eman Abd-Ellatif ${ }^{2 *}$, MScPH; Fatima Alhashmi ${ }^{{ }^{*}}, \mathrm{MScPH}$; Ali Almoqbali ${ }^{\text {}^{*}}$, MScPH; Vidyanand Vaidya ${ }^{1^{*}}, \mathrm{MScPH}$

\footnotetext{
${ }^{1}$ Directorate of Surveillance and Disease Control, North Batinah Region, Ministry of Health, Sohar, Oman

${ }^{2}$ Department of Public Health and Community Medicine, Faculty of Medicine, Mansoura university, Mansoura, Egypt

*all authors contributed equally
}

\section{Corresponding Author:}

Khalid Saif Alsaadi, BSc, MD, DEP

Directorate of Surveillance and Disease Control

North Batinah Region

Ministry of Health

Liwa

Sohar

Oman

Phone: 96899224877

Email:ka39saadi@gmail.com

\section{Abstract}

Background: Crimean-Congo hemorrhagic fever (CCHF) is a viral zoonotic tickborne disease that has been linked to a high mortality rate in a number of nations. In Oman, the first case of CCHF was discovered in 1995. The Directorate of Disease Surveillance and Control received reports of four individuals with CCHF from various places in Northern Oman between August 17 and August 23, 2019 (during the Eid Adha festival).

Objective: The aim of this study was to identify CCHF patients, determine the source and mechanism of transmission, and recommend preventive measures to avoid further outbreaks.

Methods: We arranged for a field visit with teams from the Ministry of Agriculture, Fisheries and Municipality on the same day of notice (August 23-17, 2019) in the region, and a case series study was undertaken using a semistructured questionnaire.

Results: The findings revealed that all of the patients were men (three were Omanis), ranging in age from 40 to 55 years. Three of the patients worked in slaughterhouses, and all patients had close contact with raw sheep tissues. Fever and gastrointestinal problems were the most common symptoms, with a case fatality rate of $25 \%$. Late bleeding signs and coagulopathy were detected in the patient who died.

Conclusions: The causative agent was most likely CCHF virus, and the source of the outbreak was infected imported sheep through direct contact with contaminated biological tissues, based on symptoms, signs, lab tests, and the incubation period. All imported sheep must be tested and flagged at the main gates of the three ports in Oman's north region.

(iproc 2022;8(1):e36495) doi: $\underline{10.2196 / 36495}$

\section{KEYWORDS}

CCHF; outbreak; slaughterhouse; sheep; patient 
Edited by Y Khader; this is a non-peer-reviewed article. Submitted 16.01.22; accepted 19.01.22; published 07.02.22.

Please cite as:

Alsaadi KS, Abd-Ellatif E, Alhashmi F, Almoqbali A, Vaidya $V$

Crimean-Congo Hemorrhagic Fever Outbreak in the North Region of Oman in August 2019: Case Series Study iproc 2022;8(1):e36495

URL: https://www.iproc.org/2022/1/e36495

doi: $\underline{10.2196 / 36495}$

PMID:

(CKhalid Saif Alsaadi, Eman Abd-Ellatif, Fatima Alhashmi, Ali Almoqbali, Vidyanand Vaidya. Originally published in Iproceedings (https://www.iproc.org), 07.02.2022. This is an open-access article distributed under the terms of the Creative Commons Attribution License (https://creativecommons.org/licenses/by/4.0/), which permits unrestricted use, distribution, and reproduction in any medium, provided the original work, first published in Iproceedings, is properly cited. The complete bibliographic information, a link to the original publication on https://www.iproc.org/, as well as this copyright and license information must be included. 